\title{
Pioneering the Implementation of Mosque Library as a Facility for Congregational Reading Activities
}

\section{Rintisan Penyelenggaraan Perpustakaan Masjid Sebagai Sarana Kegiatan Membaca Bagi Para Jamaah}

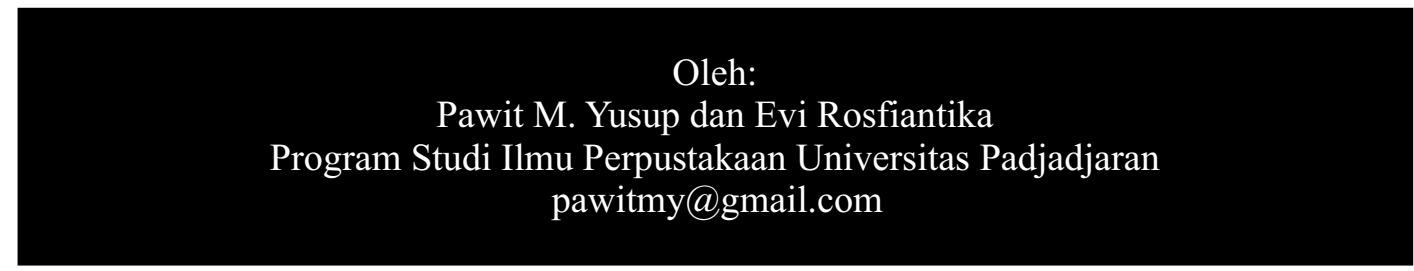

Abstract. In the context of the mosque as a place of worship widely, one of which is a mosque used as a place for education and training activities of the people. This research aims to pioneer the implementation of the library as a means of reading and studying in

the library of the mosque. The method used is the technique of PRA (Participatory Research Appraisal), with the steps: (1) conduct a discussion and shared learning about the mosque's congregation of reading and its implications for the intellectual development of Muslims in general; (2) provides a means of learning and reading in the form of a number of books on general science and religion; (3) perform activities of assistance to pilgrims in learning and reading according to specialization. Results of the study show that, since the library of the mosque, indirectly, learning activities and reading in the mosque, began to awaken. This activity in practice to be a part of the functioning of the mosque library attendance among the people.

Keywords: Mosque Library, learning activity, reading Habit.

Abstrak. Dalam konteks masjid sebagai tempat ibadah secara luas, salah satu fungsinya adalah masjid dijadikan tempat kegiatan untuk pendidikan dan pembinaan umat. Penelitian ini bertujuan merintis penyelenggaraan perpustakaan sebagai sarana kegiatan membaca dan belajar di Perpustakaan Masjid. Metode yang digunakan adalah teknik PRA (Participatory Research Appraisal), dengan langkah-langkah: (1) melakukan kegiatan diskusi dan pembelajaran bersama jamaah masjid mengenai membaca dan implikasinya bagi perkembangan intelektual umat islam pada umumnya; (2) menyediakan sarana belajar dan membaca berupa sejumlah buku tentang ilmu pengetahuan umum dan keagamaan; (3) melakukan kegiatan pendampingan kepada jamaah dalam belajar dan membaca sesuai dengan peminatan. Hasil penelitian menggambarkan bahwa, sejak adanya perpustakaan masjid, secara tidak langsung kegiatan belajar dan membaca di lingkungan masjid, mulai terbangun. Kegiatan ini pada prakteknya menjadi bagian dari berfungsinya kehadiran perpustakaan masjid di tengah umat.

Kata kunci: Perpustakaan Masjid, kegiatan belajar, Membaca. 


\section{PENDAHULUAN}

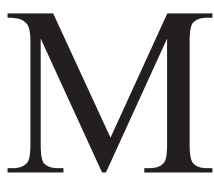
asjid adalah tempat sholat umat Islam, di mana pun masjid itu berada. Kesan

seperti itu melekat pada sebagian besar orang.

Selain itu, orang juga mengetahui masjid dijadikan tempat sholat, baik munfarid (sendirian) maupun sholat berjamaah, tempat pengajian, dan hanya sekali-sekali dijadikan tempat musyawarah dalam rangka menyelesaikan persoalan umat dan jamaah masjid secara insidental. Sebagai contoh, sehabis sholat wajib, praktis masjid menjadi kosong karena para jamaah meninggalkannya untuk suatu keperluan dan pekerjaan lainnya. Kemudian masjid ada penghuninya lagi ketika datang waktu sholat wajib berikutnya. Realitas seperti ini sudah tampak rutin, dari dulu hingga sekarang, bahkan mungkin hingga waktu-waktu mendatang, kecuali kalau ada kegiatan lain sebagai ibadah ghoeru mahdhoh yang banyak variasinya dilakukan kemudian. Selain itu, ada lagi persoalan lain yang menyangkut sedikit atau banyaknya jamaah yang hadir di masjid pada setiap kali waktu sholat tiba. Hal ini dimungkinkan karena adanya kesibukan para jamaah yang berbeda-beda.

Di beberapa tempat, masjid seolah hanya dijadikan tempat sholat wajib yang rutin dilakukan oleh umat Islam, bahkan hanya sebagian kecil saja dari umat Islam yang datang ke masjid untuk melakukan ibadah sholat. Padahal, bentuk-bentuk ibadah dalam konsep Islam banyak sekali, terutama ibadah yang termasuk kategori ghoeru mahdhoh atau ibadah selain yang sudah ditetapkan tatacara dan aturannya dalam Qur'an dan Hadis. Contoh ibadah kategori ini yang bisa dilakukan di lingkungan masjid antara lain adalah: bekerja mengurus masjid dengan ikhlas, menuntut ilmu pengetahuan di masjid, membantu orang lain berusaha lewat kendali masjid, menolong orang lain belajar membaca, menyediakan fasilitas untuk belajar dan membaca di perpustakaan masjid, berdiskusi mengenai pengetahuan umum dan keagamaan di lingkungan masjid atau di perpustakaan masjid, dsb. Jika bentuk-bentuk pekerjaan tersebut dilakukan dengan ikhlas karena Allah, maka semua itu bernilai ibadah, dan tentu mendapatkan pahala dari Allah SWT.

Dalam konteks ibadah ghoeru mahdhoh seperti dikemukakan di atas, kegiatan membina umat dan para jamaah dalam rangka untuk mengupayakan agar jamaah merasa terikat secara terus-menerus dengan masjid dengan segala kegiatannya, juga termasuk dalam praktik ibadah jenis ini. Bentuk-bentuk pembinaan dimaksud banyak jenisnya, pembinaan jamaah agar selalu sholat wajib di masjid, pembinaan umat melalui berbagai kegiatan pengajian, kegiatan saritilawah, pelatihan berwirausaha bagi jamaah remaja masjid, kegiatan pelatihan berpidato bagi anak-anak, pelatihan menjadi pendakwah cilik, pembinaan minat membaca bagi anak-anak selingkungan masjid, kegiatan berdiskusi mengenai masalah kehidupan sehari-hari, kegiatan membaca dan bedah buku yang disediakan oleh 
perpustakaan masjid, dsb. Banyak hal yang bisa dilakukan di dan melalui kendali masjid dan perpustakaan masjid. Intinya, masjid bisa dijadikan pusat pendidikan, perjuangan, dakwah, dan kegiatan lain yang bernilai ibadah.

Jumlah masjid di Indonesia jumlanya sangat banyak. DMI (Dewan Masjid Indonesia) Pusat mencatat lebih dari 700.000 masjid dan musholla tersebar di Indonesia. Jumlah itu terus bertambah seiring dengan jumlah penduduk yang beragama Islam dan juga karena perkembangan Islam sendiri. Sekretaris Ditjen Bimas Islam Kemenag Muhammadiyah Amin memaparkan bahwa peningkatan jumlah masjid dan mushala sejak awal pencatatan oleh Kemenag pada tahun 2009 cukup baik. Data tahun 2009 menunjukkan jumlah masjid dan mushala berjumlah 409.402 buah; kemudian pada tahun 2010 jumlahnya mengalami peningkatan, yakni menjadi 419.273 buah. Selanjutnya, angka tersebut naik cukup tinggi pada pada tahun berikutnya, yakni tahun 2011 yang jumlahnya mencapai 709.646 buah; naik lagi pada tahun 2012 menjadi 720.292 buah; dan pada tahun 2013, terdapat 731.096 bangunan masjid dan mmushola. (Sumber: Republika Online, 6 Mei 2015). Data tersebut dimaksudkan sebagai informasi bahwa masjid dan mushola sebagai tempat ibadah umat Islam, jumlahnya terus bertambah dan berkembang. Perkembangan ini tentu termasuk dalam kegiatan-kegiatan yang dilakukan di dan atas kendali masjid dan atau mmushola. Sejumlah sarana dan fasilitas untuk mendukung kegiatan ibadah di masjid pun tersedia di dalamnya. Sejumlah bahan bacaan berupa kitab suci Al-Qur'an, buku-buku hadis, dan buku-buku keagamaan lainnya, juga tersedia di masjid dan atau mushola ini.

Sebagai contoh, di tingkat lokal, hasil prasurvei yang dilakukan oleh tim peneliti pada awal tahun 2015 menggambarkan bahwa setiap masjid yang ada di Kabupaten Bandung, Jawa Barat, umumnya sudah memiliki sejumlah bahan bacaan, baik berupa Al-Qur'an, buku hadis, ataupun buku berkonten keagamaan lainnya. Jumlah bahan bacaan dimaksud bervariasi pada setiap masjid. Ada yang hanya terdiri atas beberapa Al-Qur'an yang jumlahnya kurang dari sepuluh eksemplar dan beberapa eksemplar buku hadis, sampai dengan koleksi bahan bacaan yang mencapai lebih dari sepuluh eksemplar. Jumah koleksi bahan bacaan yang jumlahnya puluhan dan bahkan ratusan inilah yang dalam tingkatan sederhana bisa dianggap sebagai Perpustakaan Masjid, meskipun belum sepenuhnya memenuhi kaidah sebagai perpustakaan yang memadai sesuai dengan standar perpustakaan pada umumnya, terutama perpustakaan umum.

Keberadaan koleksi bahan bacaan yang sudah ada di masjid-masjid ini, meskipun jumlahnya masih sangat sedikit, pada prinsipnya bisa dikatakan sebagai cikal bakal lahirnya Perpustakaan Masjid yang memenuhi standar penyelenggaraan perpustakaan. Fungsi dan manfaat dari bahan bacaan yang tersedia di masjid ini adalah 
untuk memenuhi kebutuhan jamaah masjid akan informasi dan pengetahuan yang bersifat pengetahuan umum dan keagamaan. Para jamaah biasanya setelah memasuki masjid dan melakukan sholat sunat dan berdoa, sambil menunggu waktu sholat wajib berjamaah, sebagian ada yang terus berdoa dan sebagian lagi ada yang membaca AlQur'an dan bahan bacaan lainnya yang disediakan oleh masjid. Demikian pula setelah para jamaah selesai melakukan sholat wajib dan dilanjutkan sholat sunat dan berdoa, sambil menunggu waktu sholat wajib berikutnya, biasanya waktu antara setelah sholat Magrib dan sebelum sholat Isya, mereka membaca Al-Qur'an dan bahan bacaan keagamaan lainnya. Bahkan setelah selesai melakukan sholat Isya, ada sebagian jamaah yang masih belajar dan membaca di masjid.

Dengan kondisi keberadaan koleksi Al'Qur'an dan buku bacaan lain yang jumlahnya tidak banyak saja, sudah dimafaatkan dengan cara dibaca oleh para jamaah. Dengan data dan asumsi seperti ini, maka jika jumlah bahan bacaan berupa AlQur'an dan buku-buku yang ada ditambah dan dikelola dengan lebih baik, diharapkan akan lebih banyak lagi jamaah yang memanfaatkannya. Kondisi seperti ini akan terus dilakukan secara rutin oleh para jamaah, sehingga dalam jangka panjang, para jamaah akan merasa terikat dengan keberadaan masjid dengan segala kegiatan dan fasilitasnya. Dan, salah satu fasilitas dimaksud adalah adanya perpustakaan masjid yang bisa memenuhi kebutuhan akan informasi dan pengetahuan para jamaah.

Atas dasar uraian seperti dikemukakan di atas, tim peneliti ingin mengkaji lebih jauh tentang bagaimana keberadaan perpustakaan masjid dengan segala fungsinya bisa mengikat para jamaah melalui kegiatan membaca bahan bacaan yang disediakannya. Dari paparan data tentang keberadaan masjid dan perpustakaan masjid sebagai bagian tak terpisahkan dari masjid dan kegiatan-kegiatannya, dapat dirumuskan masalah sebagai berikut: Bagaimana cara atau langkah-langkah yang perlu dilakukan dalam menyelenggarakan perpustakaan masjid agar para jamaah merasa senang belajar dan membaca di masjid?

\section{Tinjauan Pustaka}

Pustaka pertama tentang penyelenggaraan fasilitas bahan bacaan di masjid, yang nantinya akan menjadi perpustakaan masjid, adalah Al-Qur'an, yang merupakan wahyu Allah yang pertama kali diturunkan kepada Nabi Muhammad SAW, yakni Surat Al'Alaq ayat 1-5, sebelum ayatayat lain diturunkan. Ini artinya kedudukan dan tugas membaca itu teramat penting dalam kehidupan umat manusia. Ayat selengkapnya adalah: (1) Bacalah dengan (menyebut) nama Tuhanmu Yang menciptakan; (2) Dia telah menciptakan manusia dari segumpal darah; (3) Bacalah, dan Tuhanmulah Yang Maha Pemurah; (4) Yang mengajar (manusia) dengan perantaran kalam; (5) Dia mengajar kepada manusia apa yang tidak diketahuinya. 
Intinya, kegiatan membaca adalah wajib bagi seluruh umat manusia, dan perpustakaan masjid berusaha untuk menyediakan bahan bacaan dimaksud.

Pustaka berikutnya adalah Undangundang RI No. 43 tahun 2007 tentang Perpustakaan. Di undang-undang ini, terutama pasal 22 ayat 4, dicantumkan bahwa masyarakat dapat menyelenggarakan perpustakaan umum untuk memfasilitasi terwujudanya masyarakat pembelajar sepanjang hayat. Konteks ini mengandung arti bahwa perpustakaan umum, termasuk perpustakaan masjid, bisa diselenggarakan oleh masyarakat. Melalui perpustakaan masjid, para jamaah di masjid yang bersangkutan, atau masyarakat sekitar masjid, bisa memanfaatkan perpustakaan. Dengan adanya fasilitas dan sarana belajar berupa perpustakaan masjid yang diselenggarakan oleh masyarakat pengurus masjid, maka sedikit banyak hal ini bisa menjadi ajang silaturahim antar jamaah masjid, menjadi tempat berkumpulnya anggota jamaah masjid, dan menjadi tempat belajar bagi anggota jamaah masjid. Pada pasal 48 undang-undang ini juga mencatat hal yang berkait dengan kegemaran membaca yang diinisiasi dan difasilitasi oleh perpustakaan. Lengkapnya, Undang-undang Republik Indonesia Nomor 43 Tahun 2007 tentang Perpustakaan, pasal 48 mencatat bahwa: (1) Pembudayaan kegemaran membaca dilakukan melalui keluarga, satuan pendidikan, dan masyarakat; (2) Pembudayaan kegemaran membaca pada keluarga sebagaimana dimaksud pada ayat (1) difasilitasi oleh Pemerintah dan pemerintah daerah melalui buku murah dan berkualitas; (3) Pembudayaan kegemaran membaca pada satuan pendidikan sebagaimana dimaksud pada ayat (1) dilakukan dengan mengembangkan dan memanfaatkan perpustakaan sebagai proses pembelajaran; dan (4) Pembudayaan kegemaran membaca pada masyarakat sebagaimana dimaksud pada ayat (1) dilakukan melalui penyediaan sarana perpustakaan di tempat-tempat umum yang mudah dijangkau, murah, dan bermutu.

Sejalan dengan amanat seperti tersebut di atas, jamaah masjid bisa melakukan proses pembelajaran masyarakat melalui penyelenggaraan perpustakaan masjid. Dalam prakteknya, jamaah masjid tidak mengenal libur untuk datang ke masjid. Artinya, setiap hari sepanjang tahun, mereka datang ke masjid untuk melaksanakan sholat.

Kepustakaan berikutnya adalah seperti ditulis oleh Yusup, Pawit M. (2009) yang mengungkapkan hasil penelitian dari Kalba pada tahun 1977, bahwa hasil penelitian di Amerika Serikat menunjukkan bahwa "dalam me nghadapi sebagian besar permasalahannya, hanya tiga persen saja dari seluruh responden yang mencari informasi melalui perpustakaan". Data ini memang tidak mengenakkan bagi dunia perpustakaan pada umumnya. Di Indonesia, belum ada data yang akurat tentang itu. Namun hal seperti itu mungkin tidak berlaku untuk perpustakaan masjid, karena ada perbedaan prinsip dan cara 
umumnya dengan jamaah masjid sebagai pengguna perpustakaan. Jamaah masjid secara rutin dan setia datang ke masjid untuk melakukan sholat lima waktu, praktis tidak pernah ada libur. Dengan melihat kondisi seperti ini maka penyediaan fasilitas untuk membaca berbagai buku dan bahan bacaan lain yang bisa menambah pengetahuan dan ilmu, sangat sesuai dengan upaya pembinaan umat. Dengan disediakannya fasilitas bahan bacaan oleh perpustakaan masjid, dalam jangka panjang, jamaah atau dalam skala yang lebih luas adalah umat, akan terbiasa dan merasa terikat dengan masjid.

Pustaka berikutnya adalah Peranan Perpustakaan Masjid dalam Pembinaan Umat (Waluyo, Subagio S., 2014). Di sini Waluyo menjelaskan tentang fungsi-fungsi dan praktis. Fungsi masjid tidak hanya dijadikan tempat sholat saja melainkan sebagai kegiatan yang beranekaragam, dan semuanya bernilai ibadah. Ketika zaman Rasululloh dan Khulafaur Rasyidin, masjid ternyata mempunyai fungsi, bukan hanya untuk tempat sholat atau melaksanakan kegiatan-kegiatan yang temporer atau seremonial, melainkan banyak kegiatan di dalamnya. Contohnya antara lain: sebagai pusat kegiatan keagamaan (keislaman) dan ibadah khusus; sebagai tempat bertemunya umat Islam; sebagai pusat dakwah dan pendidikan; sebagai tempat kegiatan kemasyarakatan; sebagai tempat mencari ketenangan; dan tempat istirahat para musafir. Dari keenam fungsi di atas, agaknya yang perpustakaan masjid secara lebih operasional

relevan dengan fungsi perpustakaan masjid ialah pusat dakwah, pendidikan, dan tempat kegiatan kemasyarakatan. Sebagai tempat pendidikan umat, perpustakaan masjid sangat relevan jika dikelola dengan baik sesuai dengan prinsip-prinsip pengelolaan perpustakaan.

Lebih jauh lagi, perpustakaan masjid bisa berfungsi sebagai pengikat jamaah masjid untuk selalu datang dan memanfaatkan segala fasilits yang disediakannya. Jika dirinci labih jauh, perpustakaan masjid bisa berfungsi sebagai berikut: (1) tempat belajar umat dan jamaah masjid serta masyarakat sekitarnya; (2) tempat mengkaji dan diskusi mengenai masalah-masalah sosial dan keagamaan; (3) tempat belajar melalui membaca dengan lebih tenang; (4) sebagai tempat untuk memotivasi umat dan jamaah serta penduduk sekitar masjid untuk membaca dan mencari informasi pengetahuan dan ilmu secara teratur; (5) tempat pembinaan minat baca jamaah anak, remaja, dan orang tua secara rutin; (6) tempat didokumentasikan informasi dan sumber-sumber informasi keagamaan sehingga pemanfaatannya bisa berumur panjang himgga generasi mendatang; (7) tempat atau ajang silaturahim umat dan jamaah masjid secara rutin. Sejumlah nilai fungsi di atas jika dilakukan dan dikelola dengan benar oleh para pengurus perpustakaan masjid, akan dapat mengikat para jamaah untuk selalu merasa senang dan ikhlas dalam menjalani kegiatan beribadah di masjid.

Metode Penelitian 
Teknik PRA (Participatory Reserach Appraisal), atau dalam tataran praktik biasa disebut sebagai teknik pendampingan, digunakan dalam pelaksanaan kegiatan penelitian ini. Konsep metode PRA pada dasarnya adalah kerangka konseptual, prinsip-prinsip, nilai ideologis, visi yang ingin dicapai, serta metode yang dapat digunakan untuk mengaplikasikan pemikiran tentang partisipasi dan pemberdayaan masyarakat. Sebagai metodologi, PRA merupakan kerangka kerja yang memiliki latar belakang teoretis yang menggunakan satu paradigma tertentu. Dalam tataran pelaksanaan, metode PRA merupakan alat-alat untuk mengembangkan proses-proses partisipasi masyarakat dalam pembangunan. (Sumber: Rianingsih Djohani, 2003).

Ada banyak jenis kegiatan penelitian dengan pendekatan PRA. Jenis kegiatan penelitian, pengembangan atau penerapan program yang banyak berkaitan dengan aspek sosial-budaya dan sosial ekonomi masyarakat dikenal dengan istilah PRA, yakni penelitian yang ditandai oleh keterlibatan aktif dari masyarakat yang menjadi subjek penelitian atau subjek pembangunan. Penelitian PRA menempatkan masyarakat yang menjadi kelompok sasaran sebagai subjek dalam proses kegiatan, bukan sebagai objek. Artinya, mereka dipandang sebagai orang atau kelompok orang yang didudukkan sebagai para pelaku kegiatan, dengan tim peneliti bertindak sebagai fasilitator kegiatan. Pelaksanaan kegiatan penelitian dengan pendekatan ini dimulai dari menyusun desain, instrumen, pengumpulan data, pengolahan, analisis data sampai menyusun laporan selalu bersama masyarakat sebagai subjek penelitian.

Beberapa jenis kegiatan penelitian, pengembangan, hingga penerapan program kegiatan yang menggunakan prinsip PRA antara lain adalah: Participatory Rural Appraisal; Participatory Research and Development; Participatory Rapid Appraisal; Participatory Planning and Assesment; Participatory Learning Methods; Participatory Action Research; Participatory Learning and Action. (Kusnaka \& Harry Hikmat, 2003). Beragam jenis PRA ini lebih disifati oleh teknik-teknik praktiknya di lapangan, yang tampak dalam bentuk kegiatan yang ditekankannya. Misalnya ada yang lebih mengutamakan praktik pendampingannya, ada yang lebih menonjolkan kepada askep partisipasi masyarakat dalam kegiatan yang diprogramkan, dan ada yang lebih menonjolkan pada aspek teknik pengumpulan data untuk menyusun laporan penelitian untuk tujuan pengembangan. Selain untuk kajian penelitian, teknik PRA juga digunakan untuk kegiatan-kegiatan seperti: pembelajaran, pendampingan, perencanaan, pengembangan hingga ke penerapan program kegiatan, yang melibatkan masyarakat atau kelompok sasaran tertentu. (Handayani, Sri, 2009). Dalam penelitian ini yang dimaksud dengan kelompok sasaran adalah para jamaah masjid yang secara rutin melakukan ibadah sholat lima waktu dan masyarakat di sekitar 
lingkungan masjid.

Konteks partisipasi dalam hal ini adalah keterlibatan para jamaah masjid dalam kegiatan membaca dan menggunakan fasilitas bahan bacaan lainnya yang disediakan oleh perpustakaan masjid. Konsepsi jamaah dalam penelitian ini adalah kelompok masyarakat yang secara sadar dan keyakinan penuh, mengikuti kegiatan ibadah kepada Allah SWT. Salah satunya adalah ibadah sholat lima waktu secara berjamaah di masjid, dan ibadah-ibadah lainnya yang bisa dilakukan di lingkungan masjid.

Adapun langkah-langkah PRA yang dilakukan dalam kegiatan ini adalah sebagai berikut: (1) Melakukan pembelajaran bersama para jamaah mengenai pengetahuan dan ilmu yang bisa dibaca melalui buku dan media lain yang disediakan oleh perpustakaan masjid; (2) Melakukan penyadaran terhadap sejumlah jamaah masjid mengenai potensi yang dimiliki masjid dan jamaahnya terkait penyediaan fasilitas bahan bacaan berkonten keagamaan; (3) Melakukan pengumpulan informasi dan sumber-sumber informasi yang dibutuhkan para jamaah masjid yang bersumber pada media cetak berupa buku dan bahan bacaan lain; (4) Melakukan pengembangan model visual mengenai teknik membaca dan mengelola bahan bacaan yang disediakan oleh perpustakaan masjid; (5) Melakukan langkah-langkah penyediaan sarana dan fasilitas berupa koleksi buku dan media bacaan lain berkonten pengetahuan umum dan keagamaan, yang bisa dijadikan media pengikat jamaah masjid untuk tinggal berlama-lama di msjid dengan membaca; (6) Melakukan pengembangan model-model pemanfaatan perpustakaan masjid dalam rangka pengikatan umat terhadap masjid sebagai rumah bersama untuk ibadah; (7) Melakukan pendampingan kepada para jamaah untuk belajar membaca dan mengaplikasikan hasil bacaan sesuai dengan peminatan mereka; (8) Melakukan pemantauan secara terus-menerus atas perkembangan model membaca untuk mengikat para jamaah masjid menjadi bagian dari sistem pemanfaatan perpustakaan yang terintegrasi.

\section{HASIL DAN PEMBAHASAN}

Indikator capaian kegiatan yang nyata dalam penelitian ini adalah terselenggaranya Perpustakaan Masjid. Sebagai rintisan, perpustakaan ini diadakan di lingkungan Masjid At-Taqwa, Kompleks Permata Hijau, Desa Jelegong, Kecamatan Rancaekek, Kabupaten Bandung. Untuk tahap awal, jumlah koleksi yang disediakannya adalah 300 judul buku tentang pengetahuan agama dan umum, termasuk buku-buku berkategori TTG (Teknologi Tepat Guna). Jumlah ini akan bertambah seiring dengan tuntutan kebutuhan informasi para jamaah masjid.

Sebagai indikator tentang hasil nyata penelitian dengan basis pendampingan ini, tim penelitian melakukan berbagai langkah metodologis dan praktis terkait dengan lahirnya rintisan penyelenggaraan perpustakaan masjid ini, dengan model 
analisis perbandingan antara sebelum dan sesudah dilakukannya proses kegiatan pendampingan. Analisis tabulasi ini disusun guna memudahkan dan sekaligus memperjelas sampai di mana indikkator capaian kegiatan penelitian ini secara nyata. Dengan menggunakan 8 (delapan) indikator yang sekaligus sebagai tahapan kegiatan, bisa dijelaskan posisi sebelum dilakukan kegiatan, bentuk kegiatan, dan setelah dilakukannya kegiatan, bisa dilihat dengan lebih jelas. Ke-8 tahapan dimaksud adalah sebagai berikut:

Tahap ke-1. Sebagian besar jamaah belum mengenal Perpustakaan Masjid sebagai tempat untuk belajar, membaca, dan mencari informasi tentang pengetahuan umum dan keagamaan. Kesehariannya, masjid hanya dijadikan tempat untuk beribadah sholat wajib yang lima waktu yaitu Shubuh, Dhuhur, Asyar, Magrib, dan Isya. Bahan bacaan yang tersedia pun hanya beberapa eksemplar kita suci Al-Qur'an yang disimpan di pojok masjid.

Pada tahap ini, tim penelitian berinisiatif melakukan pembelajaran bersama para jamaah mengenai pengetahuan dan ilmu yang bisa dibaca melalui buku dan media lain yang disediakan oleh perpustakaan masjid, melalui pelaksanaan diskusi dan wawancara dengan pengurus masjid dan sejumlah jamaah. Pada posisi ini sifatnya baru pada tahapan pengenlan tentang perpustakaan dan aspek fungsionalnya. Setelah dilakukan kegiatan diskusi dan wawancara dengan para pengurus masjid dan mengan melakukan FGD (Focus Group Discussion), sebagian besar jamaah menjadi tahu dan mengenal Perpustakaan Masjid sebagai tempat untuk belajar bersama, kegiatan membaca, dan tempat untuk mencari pengetahuan umum dan pengetahuan keagamaan.

Tahap ke-2. Fasilitas bahan bacaan di masjid ini masih bersifat terbatas mengenai kitab suci Al-Qur'an dan kitab-kitab hadis, jumahnya tidak banyak dan tidak dianggap sebagai perpustakaan masjid. Hanya ada sejumlah Al-Qur'an dan kitab Hadist yang disimpan di pojok masjid. Tim berusaha untuk melakukan pendekatan secara aktif kepada pengurus masjid dengan mengusulkan agar diadakan kegiatan diskusi dengan mereka dan sejumlah jamaah masjid. Tujuan dari kegiatan ini hakekatnya adalah untuk melakukan penyadaran dengan cara diskusi intensif dan wawancara dengan ketua dan pengurus masjid terkait potensi yang dimiliki masjid dan jamaahnya untuk kemungkinan penyediaan fasilitas bahan bacaan berkonten keagamaan, sebagai cikal bakal penyelenggaraan perpustakaan masjid. Setelah dilakukannya kegiatan ini, ada indikasi hasil diskusi dan wawancara yang menunjukkan adanya keinginan para jamaah untuk ikut ambil bagian dalam rintisan penyediaan fasilitas bahan bacaan di masjid. Meskipun masih bersifat terbatas mengenai kitab suci Al-Qur'an dan kitab-kitab hadis, dan jumahnya juga masih tidak banyak, namun akan segera dilengkapi dengan sejumlah koleksi bahan bacaan yang lebih 
Tahap ke-3. Di lingkungan masjid AtTaqwa, sejauh ini belum tersedia buku dan fasilitas bahan bacaan yang berfungsi sebagai sarana belajar dan membaca, kecuali hanya tersedia beberapa eksemplar kitab suci AlQur'an yang disimpan di pojok ruangan masjid. Sudah ada keinginan dari para pengurus masjid untuk menghimpun bahan bacaan guna dijadikan cikal bakal penyelenggaraan Perpustakaan yang lebih representatif.

Bersama-sama dengan para pengurus masjid, tim peneliti melakukan pengumpulan informasi dan sumber-sumber informasi yang dibutuhkan para jamaah masjid yang bersumber pada media cetak berupa buku dan bahan bacaan lain. Untuk tahap awal, disediakan sekitar 300 eksemplar buku berkonten pengetahuan umum dan keagamaan. Tim juga berhasil mengadakan dua set lemari kaca yang akan dijadikan rak tempat buku dan koleksi perpustakaan lainnya.

Setelah tim penelitian tindakan ini dilakukan, kondisinya mulai berubah. Saat ini, sudah ada rintisan dan upaya dari para pengurus masjid untuk menghimpun bahan bacaan untuk dijadikan Perpustakaan yang lebih representatif. Pada tahap awal yang sudah dilakukan oleh tim penelitian bersama dengan para pengurus masjid adalah: disediakannya dua set lemari kaca yang berfungsi sebagai rak buku dan koleksi lainnya untuk sediaan rintisan penyelenggaraan perpustakaan masjid. Tim juga berhasil menyediakan sebanyak 300 judul buku untuk bahan koleksi tahap awal bagi perpustakaan masjid. Dari tahap inilah tim mulai bekerja sama dengan para pengurus masjid untuk melakukan tahaptahap pengembangan selanjutnya.

Tahap ke-4. Dapat dikatakan belum ada upaya dan kegiatan yang secara khusus dilakukan oleh masjid dalam hal mengimplementasikan bahan bacaan yang berkonten pengetahuan umum, keagamaan, dan bahan bacaan berkonten TTG-Teknologi Tepat Guna di lokasi penelitian. Untuk mengatasi masalah ini, salah satu upaya yang bisa dilakukan adalah mengembangkan model layanan implementatif berbasis pendampingan membaca. Pada tahap ini, tim penelitian bersama dengan para pengurus masjid berupaya melakukan pengembangan model visual mengenai teknik membaca dan mengelola bahan bacaan yang disediakan oleh perpustakaan masjid. Bentuknya antara lain dengan mengadakan diskusi dan praktek memberikan layanan pperpustakaan secara implementatif tahap permulaan. Artinya baru bersifat pengenalan.

Meskipun belum sepenuhnya berjalan sesuai dengan harapan, kondisi saat ini, di lingkungan masjid At-Taqwa sudah ada ada rintisan upaya dan kegiatan yang secara khusus dilakukan oleh masjid dalam hal mengimplementasikan bahan bacaan yang berkonten pengetahuan keagamaan, pengetahuan umum, dan pengetahuan tentang TTG-Teknologi Tepat Guna, melalui kegiatan membaca di Perpustakaan Masjid. Pola pelaksanaan layanan ini dilakukan secara 
pendampingan. Ke depan, pola layanan ini akan dikembangkan secara lebih intensif terhadap anggota jamaah masjid yang dipilih atau yang benar-benar berminat untuk menoba berwirausaha melalui eplikasi membaca buku TTG.

Tahap ke-5. Selama ini belum ada sarana dan fasilitas apapun terkait dengan bahan bacaan yang disediakan di lingkungan masjid, kecuali beberapa kita suci Al-Qur'an dan buku hadis. Keinginan untuk melakukan kegiatan menyediakan sumber-sumber bacaan selain kitab suci Al-Qur'an, sebenarnya sudah ada, namun belum terlaksana karena terkendala teknis, biaya, dan sumber daya. Setelah tim penelitian, bersama-sama dengan pengurus masjid, tim melakukan langkah-langkah penyediaan sarana dan fasilitas berupa koleksi buku dan media bacaan lain berkonten pengetahuan umum dan keagamaan, yang bisa dijadikan media pengikat jamaah masjid untuk tinggal berlama-lama di msjid dengan membaca, kondisi saat ini sudah mulai berubah. Setidaknya saat ini sudah ada lembari atau rak buku sebagai bagian dari sarana dan fasilitas untuk membangun perpustakaan masjid. Sudah tersedia dua set lemari buku dengan kapasitas 500 eksemplar. Sementara itu pada tahap awal, tim bersama jamaah baru berhasil menyediakan sekitar 300 eksemplar buku.

Tahap ke-6. Di lingkungan masjid AtTaqwa ini, secara rutin sudah ada kegiatan membaca yang dilakukan dalam bentuk pengajian rutin sesuai dengan kelompok tertentu, misalnya kelompok pengajian untuk umum, kelompok bapa, kelompok itu, dan kelompok anak-anak. Namun pada pelaksanaannya belum melibatkan fungsifungsi sumber bacaan sebagai fasilitas belajar bersama di lingkungan masjid. Tim penelitian berusaha untuk melakukan pengembangan model-model pemanfaatan perpustakaan masjid dalam rangka pengikatan umat terhadap masjid sebagai rumah bersama untuk ibadah. Melalui upaya penyediaan fasilitas bahan bacaan yang dikelola oleh perpustakaan masjid, diharapkan dapat menjadi bagian yang bermanfaat bagi proses belajar membaca bagi para jamaah secara keseluruhan.

Kegiatan membaca yang selama ini sudah dilakukan dalam bentuk pengajian rutin untuk kelompok umum, kelompok bapa, kelompok itu, dan kelompok anak-anak, akan dikembangkan polanya menjadi implementasikan hasil membacanya pada praktek kehidupan sehari-hari. Misalnya ada lomba melaporkan isi bacaan dan diberi hadiah. Yang sudah dilakukan antara lain adalah latihan pidato bagi anak-anak, latihan menjadi pembawa acara pada kegiatan kultum di saat sholat tarawih, dan kegiatan-kegiatan lainnya yang berbasis membaca dan memanfaatkan sumber-sumber bacaan di perpustakaan.

Tahap ke-7. Di lingkungan masjid, selama ini belum ada pola pendampingan membaca yang dilakukan oleh para pengurus masjid, kecuali melalui kegiatan sekolah TK dan TKA secara formal. Bersama para pengurus masjid, tim penelitian berusaha 
melakukan pendampingan kepada para jamaah untuk belajar membaca dan mengaplikasikan hasil bacaan sesuai dengan peminatan mereka. Ke depan, melalui Perpustakaan Masjid, kegiatan-kegiatan pendampingan membaca dan implementasi hasilnya bisa dikembangkan secara lebih nyata, dengan cara meningkatkan fungsi dan peran perpustakaan masjid secara terintegrasi dengan kegiatan pendidikan lainnya.

Tahap ke-8. Sejauh ini, belum ada kegiatan yang perlu dipantau terkait dengan penyelenggaraan perpustakaan masjid, karena hal ini baru merupakan rintisan penyelenggaraan perpustakaan masjid. Tim peneliti berusaha melakukan pemantauan secara terus-menerus atas perkembangan model membaca untuk mengikat para jamaah masjid menjadi bagian dari sistem pemanfaatan perpustakaan yang terintegrasi.

Kegiatan pemantauan secara berkala dilakukan oleh tim penelitian dan atau tim PKM dari perguruan tinggi, terutama Tim PKM dan Penelitian dari Universitas Padjadjarani. Perpustakaan Masjid ini nantinya akan menjadi bagian dari binaan Unpad melalui kegiatan PKM dan KKNM serta penelitian dosen secara terintegrasi.

Sampai dengan kegiatan tahap ke-6 sesuai dengan yang dikemukakan dalam tahapan kegiatan di atas, hampir semua kegiatan sudah dilakukan dengan hasil yang nyata. Hal ini bisa dilihat dengan membandingkan antara kondisi sebelum dan sesudah dilakukan kegiatan penelitian berbasis pendampingan ini.
Secara keseluruhan, proses penelitian ini sudah melakukan kegiatan dari tahap ke-1 sampai dengan tahap ke-6, dengan hasil seperti tampak dalam Tahapan kegiatan di atas. Sementara itu, pada tahap kegiatan ke-7 dan ke-8, proses kegiatan masih berlangsung, dan akan terus berlangsung sesuai dengan "rutinitas" kegiatan di masjid. Setidaknya, pada jamaah akan terus datang ke masjid untuk melakukan sholat lima waktu. Ada yang datangnya lima kali sehari sesuai dengan jadwal waktu sholat wajib, ada yang datangnya hanya tiap sore hari antara waktu magrib dan isya, ada pula yang datangnya tidak rutin karena alasan tertentu. Yang pasti, setiap hari, para jamaah masjid dipastikan datang untuk melakukan ibadah sholat. Sambil menunggu waktu sholat berjamaah tiba, sebagian dari mereka ada yang mengambil buku atau kitab suci Al-Qur'an untuk dibaca.

\section{SIMPULAN}

Dalam konteks ibadah yang lebih luas dan bervariasi, masjid adalah tempat ibadah bagi umat Islam, baik ibadah yang sifatnya tetap (mahdhoh) maupun ibadah yang lainnya (ghoeru mahdhoh). Dalam konteks ibadah yang disebutkan terakhir ini, jenisnya sangat banyak dan beragam. Salah satunya adalah masjid dijadikan tempat kegiatan untuk pendidikan dan pembinaan umat. Penelitian ini menghasilkan rintisan kegiatan penyelenggaraan perpustakaan sebagai sarana kegiatan membaca dan belajar di 
Perpustakaan Masjid. Membaca itu suruhan Allah secara langsung kepada manusia seperti tercantum dalam Al-Qur'an Surat Al-'Alaq ayat 1-5. Dan, kegiatan ini pada prakteknya menjadi bagian dari berfungsinya kehadiran perpustakaan masjid di tengah umat.

Langkah-langkah pendampingan dalam penelitian ini adalah: (1) melakukan kegiatan diskusi dan pembelajaran bersama jamaah masjid mengenai membaca dan implikasinya bagi perkembangan intelektual umat islam pada umumnya; (2) menyediakan sarana belajar dan membaca berupa sejumlah buku tentang ilmu pengetahuan umum dan keagamaan; (3) melakukan kegiatan pendampingan kepada jamaah dalam belajar dan membaca sesuai dengan peminatan. Hasilnya menggambarkan bahwa Perpustakaan Masjid bisa dijadikan sarana, fasilitas, dan media pembelajaran para jamaah masjid melalui kegiatan membaca bahan bacaan berkonten pengetahuan umum dan keagamaan. Para jamaah masjid memiliki kesempatan untuk menyempatkan diri membaca buku dan bahan bacaan lain yang disediakan oleh Perpustakaan Masjid.

\section{REKOMENDASI}

Terkait dengan simpulan ini, diharapkan agar Perpustakaan Masjid lebih banyak berinisiatif untuk melakukan kegiatan-kegiatan yang berbasis membaca buku dan bahan bacaan lain yang disediakan secara lebih terstruktur, misalnya secara terjadwal mengadakan lomba membaca puisi, pidato yang bahannya diambil dari perpustakaan masjid. Selain itu, disarankan agar koleksi bahan bacaan yang disediakan oleh Perpustakaan Masjid tidak dibatasi pada masalah keagamaan saja, melainkan dilengkapi juga dengan koleksi bahan bacaan mengenai pengetahuan umum dan bahan bacaan lain yang mencerdaskan.

\section{DAFTAR PUSTAKA}

Adimihardja, Kusnaka \& Harry Hikmat (2003). Participatory Research Appraisal: Pengabdian dan Pemberdayaan Masyarakat. Humaniora, Bandung.

Djohani, Rianingsih. (2003). Partisipasi, Pemberdayaan, dan Demokratisasi Komunitas: Reposisi Participatory Rural Appraisal (PRA) dalam Program Pengembangan Masyarakat. Bandung: Studio Driya Media.

Fjalbrant, Nancy dan Ian Malley. 1984. User Education in Libraries. Second Edition. London, Clive Bingley.

Handayani, Sri (2009). Penerapan Metode Penelitian Participatory Research Apraisal Dalam Penelitian Permukiman Vernakular (Permukiman Kampung Kota). Dimuat dalam prosiding Seminar Nasional Penelitian Arsitektur Metoda dan Penerapannya Seri 2 UNDIP Semarang, 2009.

Katz, William A. 1978. Introduction to Reference Work, jilid ke-1: Basic 
Information Sources. New York, McGraw Hill.

Riding, Phil, Fowell, Sue and Levy, Phil (1995) "An action research approach to curriculum development". Information Research, 1 (1) Available at: http://InformationR. net/ir/11/paper2.html.

Undang-undang Republik Indonesia No. 43 Tahun 2007. Undang-undang RI No. 43 Tentang Perpustakaan.

Waluyo, Subagio S. (2014). Peranan Perpustakaan Masjid Dalam Pembinaan Umat. Dewan Pengurus Cabang Partai Keadilan Sejahtera Jatiasih, Kota Bekasi.

Yusup, Pawit M. (2009). Ilmu Informasi, Komunikasi, dan Kepustakaan. Bumi Aksara, Jakarta.

Yusup, Pawit M. (2014). Membangun Komunitas Baca dan Usaha Bagi Anak-Anak Dari Keluarga Prasejahtera Di Desa Sukamukti Kecamatan Pamarican Kabupaten Ciamis. Laporan Akhir PENELITIAN IbM Dikti 2014. LPPM Unpad. 